\title{
Embodied Commons: Knowledge and Sharing in Delhi's Electronic Bazaars
}

\author{
Maitrayee Deka \\ University of Essex, UK
}

\begin{abstract}
The notion of the 'sharing economy' has recently received significant academic and non-academic attention. What the different debates have in common is an emphasis on how technologically mediated knowledge and specific social motivations enable practices of sharing. This article discusses knowledge and sharing in popular marketplaces. Based on an ethnography of Delhi's electronic bazaars, Lajpat Rai market, Palika Bazaar and Nehru Place, this article suggests ways to think about knowledge that are embodied and practice-based: What is such embodied knowledge? How is it created and shared? The article argues that bazaars combine sociality established through face-to-face bargaining with informal trade arrangements to enable co-creation and collaboration around technological products. The resulting knowledge is tacit in nature and is mimetically transmitted between bodies. As a result, the bazaars feature a kind of sharing that is distinct from what is understood by most accounts of the sharing economy.
\end{abstract}

\section{Keywords}

collaboration, co-production, openness, tacit knowledge, trade skills

\section{Introduction}

The term 'sharing economy' offers new ways to conceptualize collaboration and competition. Participants in the sharing economy collaborate in sharing knowledge and in cocreating goods and services. At the same time, they compete as economic actors on a market. This combination of collaboration and competition is understood to be the truly novel and distinguishing feature of the sharing economy. Non-academic writers like Botsman and Rogers (2010) are generally optimistic about it, seeing such market-based collaboration as harbouring the potential of a reformed market economy, an 'ethical economy' where virtue and value increasingly coincide (Arvidsson \& Peitersen, 2013).

\section{Corresponding author:}

Maitrayee Deka, Department of Sociology, University of Essex, Wivenhoe Park, Colchester CO4 3SQ, UK. Email: maitrayee.deka@essex.ac.uk 
Academic perspectives are more mixed. Some are moderately hopeful and understand the new forms of collaboration showcased by the sharing economy to harbour the poten-tial of a new re-embedding of a market economy that has become too detached from social concerns (Benkler, 2004, 2010; Kostakis \& Bauwens, 2014; Pais \& Provasi, 2015; Polanyi, 1975). Others are less enthusiastic and suggest that this combination of collabo-ration and market competition leads to a further subsumption of digital labour in the form of a 'gig economy' combined with a 'platform capitalism' where the very capacity to create a common world is subsumed and commodified in new and more far reaching ways (Fuchs, 2014; Scholz, 2016).

All these perspectives, academic and lay, critical and hopeful, share a common basis in the literature on digital labour, knowledge work or the information economy that has developed since the early 1990s (Adler \& Heckscher, 2006; Castells, 2000; Dupuy, 2004; Dyer-Witheford, 2015). In that tradition, collaboration has been understood as the defin-ing characteristic of contemporary digitized knowledge work, and such collaboration has often been understood to clash with established logics of market exchange or capitalist control, potentially embracing a new contradiction that points towards a different kind of 'postcapitalist' knowledge economy (Mason, 2015). This literature has evolved out of an almost exclusively empirical focus on Western manifestations of the digital economy: either corporate practices of knowledge work or alternative circuits of peer production (Benkler, 2006) or Hackerdom (Coleman, 2013; Kelty, 2008).

At the same time, however, the rapid diffusion of digital goods like cell phones, computers and video games outside of the Western heartland has fostered quite different forms of knowledge creation and sharing. Indeed, the combination between the elevated knowledge content of these goods and the specific skills needed in handling them on the one hand, and the informal contexts in which they circulate in the 'pirate economy' (Liang \& Sundaram, 2011) outside of the spaces of corporate globalization on the other, have led to a revitalization of pre-existing bazaar modes of organization. As an economic system, bazaars are unique spaces of commerce that use traditional and informal net-works of knowledge both for the distribution of goods as well as for price determination. Clifford Geertz (1963, 1978) suggested that the 'information asymmetry' that character-ized traditional commercial places leads to the development of an informal infrastructure of knowledge. Unlike modern and formal spaces of commerce such as supermarkets and retailers, bazaars do not always have 'market devices' (Callon, Millo, \& Muniesa, 2007) like pricing, advertising and recognized channels of distributors. As a result, the bazaars depend on the resources at the disposal of the people, to compensate for individual actors' lack of specific knowledge and for the absence of sophisticated price setting mecha-nisms. This creates a unique sharing idiom in the bazaars, at the heart of which is a suc-cessful market transaction.

In this article, I will explore one such bazaar knowledge economy, Delhi's Palika Bazaar, Nehru Place and Lajpat Rai market. With support from empirical examples, I will argue that the bazaar model exemplifies a different way of merging collaborative knowledge and market competition. The difference lies mainly in the bazaar mode's reliance on informal networks and on tacit rather than theoretically codified knowledge. What is shared is not so much a corpus of codified knowledge that can be attributed to individual creators (as in the case of lines of codes deposited on Github, or potentially 
patentable innovations) as much as an embodied commons (Esposito, 2016) made up of practices and tacit competences.

To some extent, the contemporary bazaar model of collaboration continues forms of sharing that have been common to market practices throughout history. The bazaar remains embedded (Granovetter, 1985) in existing social networks and cultural institutions (sharing and 'community' was, after all, a defining feature of Clifford Geertz's [1978] classic account of bazaars as a form of 'peasant marketing'). At the same time, the different knowledge content of the goods that are bought and sold in electronic bazaars in Delhi radically transforms such traditional practices, making the electronic bazaars an example of a different model of collaborative knowledge creation. This combination of novelty, the latest electronic product in the market and historical continuity in the way of informal channels of knowledge accumulation and price setting makes the example of electronic bazaars a potential source for new perspectives on the sharing economy.

In the Western literature, the closest model to the Delhi bazaars appears to be the artistic laboratories where different participants cooperate around a product. Becker's (1974) idea of 'collective action' highlights the cooperative network of suppliers, dealers and consumers that bring an artist's ideas to life. However, studies of bazaars do not have to confront the kinds of 'creator'- centric discourses that are prevalent in 'art worlds'. Bazaars do not have isolated creators. This has to do with the transformation that a prod-uct undergoes as it moves among a mass of 'creators'.

To include bazaar-based forms of knowledge in the discourse on the 'sharing economy' is not an attempt at redefining that concept. Instead, this essay seeks to bring to notice how often-ignored informal commercial arrangements and traditional set-ups have been upgraded to co-create and collaborate around technological products potentially making information products available to mass consumers around the world. In the first part, I discuss the bazaar model viewed from a sharing economy perspective. Following this, I briefly describe the field and go on to analyse the forms of knowledge sharing that is found in the bazaars. I show that knowledge is tacit, and exists in the body through tactility, repetition, copying and experimenting with everyday tools. I go on to argue that the sharing of practice-based knowledge brings a unique link between compe-tition and collaboration centred on face-to-face market exchanges. Collaboration is fur-ther understood to unfurl through a sense of mutual indebtedness, or, if you will, a sort of embodied commons. Finally in the conclusion, I relate my findings to the overall debate on the 'sharing economy'.

\section{Bazaars and the sharing economy}

In recent years, the debate on the sharing economy has given us two important models along the lines of which sharing, as a social phenomenon, has been understood. We have the Uber and Airbnb type of actors that have increasingly come to represent a corporate model based on capital expansion. On the other hand, we have activist-led movements such as free software and open source as well as fab labs and maker spaces that want to be socially relevant, while at the same time ensuring their sustainability by being part of a market economy. Although broad, these two models of the sharing economy are not representative of all the different models that operate on the ground. Apart from the more 
obvious neglect of non-Western models, there is also a lack of dialogue with existing practices of sharing, whose infrastructure precedes an information economy, such as, importantly, bazaars.

At a much earlier point in the debate about knowledge production in the information economy Eric S. Raymond's classic essay The Cathedral and the Bazaar hinted at the existence of traditional models that have perfected ways of sharing knowledge and skills. In the essay, he discusses the corporate and free software models using the tropes of, respectively, the Cathedral and the Bazaar. The corporate model works as a cathedral in that knowledge is closed and private, much like in the secretive masonry guilds that built Europe's great Gothic cathedrals. Conversely, free soft-ware operates as a traditional bazaar in that knowledge is open and access remains unstructured (Raymond, 1999). Many CBPP communities (Commons-Based Peer Production - an important aspect of the 'sharing economy') continue this distinction where the merit of the bazaar model is represented in the ability to collectively write strings of code. CBPP parlance valorizes professional knowledge, whether to do with the knowledge of programming language, or the knowledge and skill to work on complex machines such as 3D printing and Arduino microcontrollers. Apart from programming, the specialized knowledge also includes proficiency with social media tools to develop community knowledge as well as reputation for individual members (Gandini, 2016). Unwittingly, such knowledge reinforces an elitist network of knowledge workers and activists.

While Raymond does an important job of introducing the open scape of the bazaar into the discourse of an information economy, his analysis does not capture the full potential of bazaars as practice-based knowledge systems. He does not delve empirically into the forms and infrastructure of bazaari knowledge and thus, in a sense, continues the process of excluding traditional knowledge and sharing practices as aspects of the shar-ing economy. That is why it is interesting to include an empirical study of the bazaars into the discourse of the sharing economy to extend formerly ignored spaces - in this instance that of markets which have created their own ways of acquiring knowledge to counter information asymmetry, and attract new consumers.

\section{Methods}

This article is based on an ethnography with traders of video games in Delhi's electronic bazaars, Lajpat Rai market, Palika Bazaar and Nehru Place. Most of the insights from the field come from free flowing conversations with different traders, shop assistants and street vendors. With a few traders, I developed a closer rapport; their names recur in the article. Apart from conversations, and structured interviews, observation was central to the collection of data. Up to now, I have spent a total of 15 months in the markets. I spent 12 months, between September 2012 and September 2013, then a month in January 2015. I revisited the markets in the months of March and April 2016.

Lajpat Rai market is a wholesale electronic market in the Chandni Chowk area of old Delhi, overlooking the historic Red Fort. In this market, I spoke to around 15 traders of video games. Palika Bazaar is India's first underground air-conditioned retail market selling a paraphernalia of goods, including electronics. At Palika, I interacted with 30 
traders and shop assistants. Nehru Place is a popular computer retail and hardware market in south Delhi. I interviewed approximately 50 street vendors here.

In the subsequent sections, the essay describes the tacit nature of bazaar knowledge. There is further a discussion on the informal channels of knowledge acquisition to bring out the uniqueness of the bazaar model of knowledge and sharing.

\section{Bazaar knowledge}

Technological knowledge has been at the centre of a sharing economy. Internet-based platforms and digital artefacts have created networks to share physical resources as well as to develop scientific and technological knowledge in furthering the infrastructure of 'social sharing'. Physical bazaars became part of technological knowledge when they started dealing in advanced electronics in the last decades of the twentieth century. However, their relation to technology was not limited to merely selling technological products. Bazaar actors actively engaged with technology, creating new life chances in an urban economy. In his book Pirate Modernity: Delhi's Media Urbanism, Ravi Sundaram (2010) discusses Delhi's electronic bazaars as the harbinger of a different media economy and aesthetics. He argues that the informal pirate economy has been important in making media products a part of the life of ordinary people. The marginal-ized market actors have made a foray into the informal information economy by finding ambiguities in the organized sector, particularly in the legal system. Their renegade spirit is highlighted in the ways in which small-scale traders resorted to piracy to enter the market of highly priced technological products (Lobato, 2014).

Piracy and flexible knowledge networks encourage a tradition of backyard tinkering - for instance, markets like Lajpat Rai sell Lara TV games that have been assembled by local traders with additional parts imported from China. Bazaars traders also repair and restore old consoles. Tinkering with things like integrated circuit boards and Chinese chips, old cartridges and TV games, 'zombie media' are brought back into circulation in the local markets (Parikka, 2012). Small-scale traders hack into new consoles, the mod-ding of which enable them to be used to play outdated or pirated games. Some tinkering is as basic as illegally downloading computer games on CD and DVD.

The following section describes the informal processes of accumulation of knowledge about video games.

\section{The social stock of knowledge}

As the schools of phenomenology, ethnomethodology and social interactionism have pointed out, 'theoretical knowledge' is not the only way in which actors make sense of their worlds. 'Everyday knowledge' exists in the form of social customs, innuendos, myths and rituals:

... theoretical knowledge is only a small and by no means the most important of what passes for knowledge in society ... The primary knowledge about the institutional order is knowledge on the pretheoretical level. It is the sum total of 'what everybody knows', about a social world, an assemblage of maxims, morals, proverbial nuggets of wisdom, values and beliefs, myths, and so forth. (Berger \& Luckmann, 1967, p. 65) 
In Delhi's bazaars, an important part of the knowledge exists as an oral tradition, that different actors use and circulate. In developing the concept of 'joint action', Herbert Blumer (1969) mentions stories that act as an anchoring narrative to compensate for the contingencies of reality. Blumer observes that interaction among a range of actors is made highly effective by stories acting as a collective structure. The bazaars, which do not have institutional structures of knowledge, use circulating narratives of games to make video games intelligible in their everyday life. As one trader enumerated:

First came Atari games, and then came 4-bit games with graphic card, then 16-bit games. We have after that PlayStation 1, which was 32-bit, and PlayStation 2 that came with 64-bit. It went on like that. Over the years, we have seen an improvement in the graphics of games.

Knowing the timeline of different machines (viewed from the hands-on perspective of the materiality of their parts) is a way to enter, appropriate and claim a video gaming world that is otherwise elitist and esoteric. Outside of a professional network and a cul-tural world of elite gamers, this oral tradition of intimate technical knowledge is the most useful way to start any conversation about video games. When in front of his consumers, a new trader confidently reproduces the timeline of consoles; he disguises his lapses in professional knowledge. For the experienced trader (who has been in the market since the 1980s), the oral tradition provides a sense of accomplishment of having seen the evolution of a commodity in the market. In the absence of written manuals and hand-books, the social stock of knowledge doubles as a collective repository of a product.

\section{Personal knowledge and ways of doing}

With each new product, traders add to their knowledge. Traders have to know the hardware of a new console thoroughly. Without this knowledge, they miss out on important repair work. A major part of this knowledge starts from experimenting with new technol-ogy. To quote from my field notes:

In early 2000, when he visited Nehru Place, Vivek was eleven years old. Many of his friends had dropped out of school and were selling pirated games and software in the market. Seeing the quick money his friends were making, Vivek left school to join the market. In the initial days, he did not know anything about electronics. He would spend the whole day calling out for consumers and then take interested consumers to a senior technician for repair work. One such day, finding his senior absent, he obtained a computer from a client. Vivek did not know anything about computers. He steadied his hand on the mouse and pressed different keys. He was unable to fix the problem, but after that day, he became less nervous around technology. Henceforth, Vivek worked on several versions of computers. In the beginning, he could not read and write in English. In order to run the computer, he would memorise the letters on the screen. For instance, he memorised that in a Widows computer, if he went to the bottom left corner of the screen then he saw S T A R T. If he pressed START, then he came to a combination of letters, each with their own functions. Over the years, these associations became more automatic. Most new skills Vivek learnt through a trial and error method. He approached computers with an easy mind normalizing the aspect of damaging the system. In case he ruined it, Vivek had the possibility of taking it to a better technician and in the worst-case scenario 
could replace the damaged parts. Vivek knew big misfortune was not an everyday

phenomenon and one did not learn new things by being cautious.

Bazaar knowledge is what Michel Polanyi calls 'tacit knowledge' (Polanyi, 1983). It is a way of doing things through a set of rules that are not consciously followed and are generally learnt through experience (Polanyi, 1958). This is exactly the way in which bazaar traders put their knowledge into use. When asked how they learnt to do a particular thing, they are unable to provide a coherent account. But they can always perform what they know. This signifies a primary character of tacit knowledge that puts the emphasis on know-how rather than know-that. Moreover, "knowing how to "do things" is not reduced to language or any other putative "part" that allegedly "explains" performance' (Ray, 2009, p. 80).

Everyday tools support the hands-on approach to technology. When a bazaar trader experiments on a machine, he uses the things around him as tools. The shop-desks are littered with items that have proved their value after changed usage. As a result, one finds a gas lighter, pieces of cotton, glue and rubber bands that have attainted the same status of tools as more specific objects like screwdrivers and soldering wire. A tiny piece of cotton can solve many problems. Lumps of cotton exert pressure on the motherboard to make a particular chip function. At times, the same piece of cotton helps in ably closing a console cover.

Alongside tools in the shop, there are different machines. The shops have obsolete cartridge games, and abandoned consoles. They also have pieces of hardware stripped from different machines and chips imported from China. Whenever a problem is brought to a trader, he tries to solve it by working with different objects in his shop, without fol-lowing any specific method. He follows the trail of previous successful tinkering and trusts his intuition. Regularly, traders learn new things purely by accident. A trader in Palika Bazaar discovered that a faster way to open a PlayStation console was to hit the corners of the machine without having the need to unscrew individual bolts. And many a time, they alternate repair work between different gaming consoles.

The traders will take advice from other people in the shop. In the middle of repairing a console, it is not unusual for a trader to suspend his approach to try another one. For instance, if another trader suggests that the solution to the problem at hand is to replace a chip from another version of console, then the trader follows suit. The casual attitude that bazaar actors use to approach technology is unique. We have seen that practitioners of free software projects such as Debian put a great deal of emphasis on the knowledge and contribution of individual members. To say to someone RTFM (Read The Fucking Manual) is a way to indicate an individual's lack of technical knowledge (O'Mahony, 2006). In the bazaars, however, a different scene is enacted: the industrious nature of the bazaars is put to its maximum use. Whoever enters the shop can contribute to the ongo-ing technical process. Often times these contributions do not even figure as genuine concern but come from a person's curiosity to be part of a creative process. In order to solve a problem of a console, questions that prompt a trader into action are as casual as 'why don't you try re-packaging the system?' or 'do you think it is a problem of the lens' or 'have you checked the BIOS (basic input/output system)?' No doubt, a trader has his sense of useful and redundant knowledge, but that does not mean that he will outright 
reject the suggestion coming from different people. He listens to what the other person has to say with a view that it has the potential of leading him to a new product.

\section{Collaborating with friends}

When the Xbox One was released in 2013, Lalit spoke to people in Palika Bazaar to understand the new console. He was keen to talk to his immediate circle of friends. Among his friends was a trader based in Kolkata, a metropolis in the eastern part of India. Also he counted as friend his former employer from Lajpat Rai market. All of them were planning to sit together and 'brainstorm' about the consoles. Lalit was looking for-ward to the three of them bringing their respective skills to the table. He and his friend were good with hardware while his former employer knew more of software. They hoped to unravel the changes made to the security configurations of the new console.

Within a friend network, the knowledge that is co-created is of a more specific nature. The traders are likely to share trade secrets that are not discussed everyday in the bazaars. Collaborations with friends happen in more organized surroundings, and do not have the same degree of chance that is part of everyday tinkering. Usually with friends, the traders discuss things with a more focused approach and conversation is not left open-ended. When friends gather for work, they have a particular technical problem to solve and they try to reach that objective.

\section{Collaborating with customers}

The bazaars are part of an ecosystem of improvising, the focus of which is the daily consumers. One of the criticisms that the sharing economy has faced is that its actors are unable to produce much in terms of actual use value (Arvidsson et al., 2016). Collaborative platforms often lie dormant and underutilized. Many innovations cater primarily to the political or ethical visions of their inventors, and not to an actual consumer demand. Or, alternatively, their use value is projected into the future. They promise to disrupt markets practices, but such promises might have little relevance in the present. To quote Zaleski's example: the actors behind the $3 \mathrm{D}$ printer Makerbot claim that ' $3 \mathrm{D}$ printers would become as common as microwaves. Just one problem: no one else shared that dream' (Zaleski, 2016).

Instead, when the bazaar traders bring a new product to the market, they anticipate what would work for the consumers. The emphasis is for the product to fit to the needs of the customer and not vice versa. For instance, one of the improvisations that pirate markets made to the Grand Theft Auto games was to place the characters in Indian cities and local settings. GTA: Punjab was a game that did very well in markets like Nehru Place. Gamers mentioned that they enjoyed seeing the main characters dressed in desi (native) attires and the 'cheats' in the game allowed them to make significant changes to the gameplay.

Not only is the consumer the focus when thinking about the next possible product, he or she is also an important information source. The traders use their interaction with consumers to know about the gameplay. They cannot individually play each and every game that is out on the market. A lack of knowledge could make the trader lose a 
potential client. This leads traders to seek 'bargaining cues' in every conversation with consumers. By speaking to different gamers, Govind understood the specificities of the game Hitman: Absolution. He found out that many gamers were having problems cross-ing the third ('Terminus') and fourth ('Run for your life') levels of the game. Govind used this information to haggle with other gamers. If he found out that the gamer was lying about any particular stage, he employed the knowledge acquired from a previous consumer to get an upper hand in the bargaining process.

While the traders have the market exchange in mind, the conversations about games develop in a dynamic environment. A consumer likes to share information about game with a trader because he looks forward to the discussion that ensues. Both parties come with strong opinions and the agreements and the disagreements open a product to new sets of ideas and possibilities.

\section{Collaborating with importers and distributors}

The importers and distributors of locally manufactured video games are another node of the network-based knowledge in the bazaars. The distributors of locally manufactured games arrive in a shop with a variety of consoles, remote controls and adaptors. The distributors elaborate the features of a new product, urging the trader to buy it. In July 2013, I was part of a conversation between distributor Vijay and shopkeeper Bharat at Lajpat Rai market. Vijay was trying to sell a new cartridge game.

Vijay: This product is doing really well in the market. Just now, Rajat has ordered 20 pieces.

Bharat: I know about it but I have heard the battery back up is not good. I do not want to hear any complaints from the customers. They will arrive at my shop every other day.

Vijay: No! The battery back up is normal. Order the item now or you might need to buy it at a higher rate if the company increases the price.

Bharat: Well, you people talk and leave, we are the ones who have to face the customers. Do one thing, just leave 10 pieces now, and let's see how the customer response is.

Apart from local distributors and importers, the traders are in constant contact with suppliers in China through instant messaging apps such as QQ. It is interesting to note that street level traders in India and China along with hackers are part of a transnational trade and innovation network. To give an example: Delhi bazaar traders were having a prob-lem to hack into PS3. Jaspreet, a trader in Palika, suddenly discovered that someone had posted a hacking file in PS3hax.com. It was removed almost immediately but not before many traders like him had the chance of downloading the file. Now he says, that Chinese traders made chips with the same software, making it easier for small-scale traders to modify PS3 consoles.

The transnational network of hackers and traders acts as an alternative circuit of shar-ing and co-creation of knowledge outside of 'authorized' channels (Nakassis, 2013). Commerce is the focus of such collaborations. In that regard, such networks are not any 
different from any pre-existing trade networks. However, the reason for including such networks within the discourse of the sharing economy is the to and fro exchange of technical knowledge. At times, traders are part of WhatsApp groups made up of suppliers and other traders, where they share their knowledge about new technology on a daily basis. The traders get excited about new products, and they throw a volley of questions to sup-pliers if they see a new product. In the stream of text messages, there is a breakdown of the properties of a product. Usually a trader does not put in an order unless he is satisfied with the features of a product: the hardware configuration, accessories, battery back-up, repair possibilities and its user-friendliness. At the base of commercial networks, there is a vibrant process of knowledge sharing that keeps the markets buoyant.

\section{Collaboration and competition}

One of the classic paradoxes of the sharing economy is that it combines collaboration and competition. As recent studies have shown, most communities have emphasized one aspect at the cost of the other (Bardhi \& Eckhardt, 2012). On the other hand, the whole existence of bazaar level knowledge rests on the balance between competition and col-laboration. Different actors compete over market transactions and they cooperate and collaborate to compensate for the information asymmetry. The interdependent trade net-works are intrinsic to a market economy. It does not so much function as capitalism, in Braudel's sense of monopolies of 'antimarkets' (Braudel, 1977). Rather it is about the 'making a living rather than to accumulate wealth' wherein Braudel locates the 'small exchange' of more modest everyday markets (Howard, 1985).

Together with the face-to-face commercial exchanges, the market ethic is another aspect that combines competition and collaboration. Bazaar actors do not have ethical and ideological considerations outside of their immediate context. As Geertz argues, 'the bazaar economy, in such a situation, necessarily develops an ethic of its own, for ordered sociality can proceed without normative control. But the ethic thus evolved is so pre-cisely adjusted to person to person, higgling and haggling, credit-balance peddling' (Geertz, 1963, p. 139). An ethic intrinsic to commerce prevents the bazaars from becom-ing monopolistic on the one hand and impractical on the other.

\section{Knowledge transmission in the bazaars}

One of the crucial ways in which knowledge transmission in the bazaars stands apart from CBPP communities is the importance of informal networks. Prominent sharing economy communities, whether Airbnb or co-working spaces, mostly have formalized sets of rules and regulations when it comes to integrating new members into the group. It can go from a basic process of registration to a complex process of developing reputa-tion among the various members (Gandini, 2016). It is therefore not surprising that many of the CBPP communities, and in particular more activist-oriented communities linked to those of the free software movement, have been critical of informal models of knowl-edge creation and sharing (Liang, 2010). Activists understand pirated practices such as modding and illegal downloading of software and video games to be problematic. These practices however have been crucial to the development of bazaar knowledge and forms 
of sharing. Apart from pirated practices, other informal networks of trust relations form the basis of bazaar-based knowledge transmission (Thompson, 2011).

Copying is one of the ways in which knowledge is shared and transmitted in the bazaar. Copying is rampant through copying software as well as small time hardware tinkering. If we break down copying practices between those who copy and those whose ideas are copied in the bazaars, it emerges as a way to survive in the market.

Govind in Palika Bazaar kept numerous second hand DVDs in his shop. He repackaged the used DVDs to give them a new look or at least to make them appear in good working condition. Seeing Govind's trade of second hand games doing well, after a month or so other traders started selling the same. Rajat in Lajpat Rai introduced a new product to the market by attaching an old TV game to a bigger screen. With the market for old TV games dwindling, Rajat's product revived an obsolete video game, giving the impression of an arcade game to what is essentially a TV game. Rajat's product was widely copied in the market.

When I asked Govind and Rajat about how they felt about having their product widely copied, they had similar things to say. They were not preoccupied with acts of copying. Both looked at the situation from a pragmatic point of view. As Rajat mentioned, 'we came to the market empty handed, whatever we are today we are because of the market. We have always learnt from other people by observing them and talking to them. We have borrowed tools from other traders when we needed them. Suddenly we cannot say this is yours and that is mine. We are dependent on one another.' Govind forwarded simi-lar sentiments when he said he was okay with other people copying his product, as he could be the next person who might have the need to do so himself.

Customary transmission of knowledge is another way in which knowledge is passed from one individual to another. This aspect comes about through the relationship that a shop assistant has with his employer. In the absence of any formal degree or training, the shop assistant learns most of his skills by observing a senior tradesman. Lalit, a trader in Palika, has hired a new assistant, Harish. Harish's knowledge of electronics was limited to his own personal experience of repairing household appliances. He came to Palika with no knowledge of video games. Lalit hired him seeing his enthusiasm and willing-ness to learn about games. They sat side by side by on two desks. On several occasions, Lalit asked Harish to observe how he installed a pirated software following the 'read me' section. Within a couple of months Harish learnt the basics of repairing and was able to lend a hand to Lalit.

Customary usages tie the transmission of knowledge between a trader and his assistant. The shop assistant calling his employer 'ustad' ('master', a term that has its origin in the nineteenth-century crafts community [Roy, 2009]) makes this relation informally binding. Within the traditional master-student relationship, a student does not outgrow the relationship of reverence and trust even after he leaves his master's workshop. In the bazaars, a trader shows respect to his ustad and towards him there is a sense of perennial indebtedness. Years after leaving his master's shop in Lajpat Rai market, Lalit never refuses any call from him. He offers help to his ustad: working on damaged consoles that his ustad can not resolve and running errands for him. Whenever Lalit speaks of him, there is a pride in his voice, 'in the market, when it comes to technical knowledge, nobody is better than my ustad'. 


\section{Embodied commons}

This section reflects upon the theoretical underpinning of practice-based bazaar knowledge. The work of Italian philosopher Roberto Esposito (2010) becomes a way of conceptualizing what such informal models of sharing say about the notions of community centred on the body. To Esposito, communities are constituted by a common sense of obligation or debt (the original sense of the Latin munus). As he puts it:

... the munus that communitas shares isn't a property or a belonging (apparatenenza). It isn't having, but on the contrary, is a debt, a pledge, a gift that is to be given, and that therefore will establish a lack. The subjects of community are united by an 'obligation', in the sense that we say, 'I owe you something' but not 'you owe me something.' This is what makes them not less than the masters of themselves, and that more precisely expropriates them of their initial property ... namely, their very subjectivity. (Esposito, 2010, p. 6; original emphasis)

Similar to Esposito's conceptualization, community in the bazaars is understood as something one enters with a lack. The traders do not have the resources to possess basic things such as a wide range of tools. They also do not have expensive products, for instance, brand new gaming consoles and accessories. It is a common occurrence for a trader in need of a particular tool to borrow it from his fellow traders. Moreover, if a trader has a consumer looking for a specific model of a game, and he does not have it in his shop, he will acquire it from another shop.

Just as with the case of tools and products, the same process also applies to the learning of new skills. Many of the traders do not come with the privilege of formal education. Especially with regard to the Nehru street vendors, this aspect is crucial. Growing up in slum areas around south Delhi, many of them did not have the resources to attend good schools. Among other things, bullying and adolescent violence pushed these young men to drop out of school at a young age. Also, the absence of luxury products such as personal computers at home did not provide alternative avenues for the street vendors to acclimatize to new technology. They eventually learnt how to use computers in the market with the aid of senior repair persons and their friends. Likewise, the traders in Lajpat and Palika did not enter the market trained in the workings of a computer or video games. Knowledge about products developed by talking to the other people in the market, observing them at work and also directly approaching others for help when they were stuck with a problem.

Not only does Esposito's work throw light on the interdependent trade networks, he also explicates what can be an anchoring point of collaborative practices. In Persons and Things, Esposito (2016) sees the body as the third element that breaks the person/thing binary. Especially, he considers biotechnologies and transplants that complicate the rela-tionship of a single person owning a transplanted organ. Rather, he argues, the body acquires a kind of 'trans-individuality' and 'allow[s] a shifting of the concept of body from the property of a person to a common good' (Serafini, 2017, p. 217).

In the bazaars as well, the body becomes a basis for 'trans-individuality'. Without institutional training, original creators or manuals/texts, knowledge is cultivated in the bodies of the traders. Tacit knowledge is the way in which new knowledge is registered. It has to do with the ways their fingers move adroitly, and how their eyes are trained to focus on the tiniest of chips on a motherboard. While an individual trader's body carries 
common knowledge, the 'body' of knowledge expands when other traders learn from mirroring his movements. The mimetic body attains a trans-individual status where each learns to work as the other and thus evokes a collective body. Furthermore, there is no sense of ownership. In this way we can clearly see how the body in the bazaar works as a 'common good' (Vähämäki, 2005). The movement away from individual knowledge to the frame of the body that absorbs everything and is open for mimesis explicates knowl-edge and sharing in the bazaars. Mimesis happens at a subconscious level when a par-ticular trader reproduces what he has memorized over time in his work. His knowledge of a particular skill is an imitation of what he did the day before and the day before that. At other times, it is a conscious process of following how a senior trader repairs a broken console. Embodied knowledge, whether it is in the manner of speech or oral tradition or in the manner of doing, is common and communal. The moment a trader uses his fingers on the motherboard, the process is available to everyone who is around him. The moment he speaks about improvisation colloquially, it is an education for interested listeners and a prompt for new conversation.

Starting with a trader's own situation of lack of skill, knowledge and tools, he fills his own lacunae by acknowledging and benefiting from the interexchange between different market actors. As the body becomes a creator and storage for new knowledge, mimesis creates a trans-individuated community. A serious consideration of Esposito's idea opens the possibility of understanding the bazaar model not just as a way of doing but also as a model that can offer theoretical acuity when it comes to imagining a community that is not centred on individual reputation and profit incentives.

\section{Conclusion}

What is distinctive about the collaborative practices in the electronic bazaars? How are these practices distinguished from the forms of embeddedness and cooperation that are a necessary feature of all empirically existing markets, and to what extent can they be said to represent 'sharing' as a sociologically novel and theoretically interesting phenomenon?

A view from Delhi's electronic bazaar gives two possible answers to that question. On the one hand, the proliferation of a popular digital economy, a 'globalization from below' (Mathews, 2007) made up of pirate and street markets, suggests the salience of a differ-ent kind of collaborative knowledge economy based on tacit rather than codified, embod-ied rather than discursively abstracted knowledge. It is a popular knowledge economy distinct from the elite, or at least middle-class, phenomenon generally associated with the sharing economy. The semi-legal networks of creation and distribution of electronic products to the non-elite consumer suggest that this is a venue for further expansion of the digital economy.

On the other hand, the contrasting scenario to the bazaars indicates a certain overemphasis on 'sharing' and collaborating in accounts of the sharing economy. After all, close ethnographic accounts of the bazaars suggest that sharing and collaboration is a feature of most forms of market exchange. In this respect the Airbnb host's effort to cocreate an experience of conviviality by sharing local knowledge and affective commitment is no different from the shop owner drawing on shared language, culture and what 
I have called a body-in-common in co-creating an experience of conviviality that allows for a furthering of the haggling process. Seen in this way, the emphasis on sharing, and its political and ethical potential in the established account of the sharing economy, might very well be the consequence of a theoretical construct, common to established Western or 'Northern' (Connell, 2007) social theory, in which the everyday conviviality and embodiment of markets and market practice have been underemphasized in favour of a theoretical model that instead over-emphasizes the rational and impersonal nature of market exchange (Beckert \& Aspers, 2011). A less parochial view might be able to bal-ance this account.

\section{Funding}

This research received no specific grant from any funding agency in the public, commercial, or not-for-profit sectors.

\section{References}

Adler, P., \& Heckscher, C. (2006). The firm as collaborative community: Reconstructing trust in the knowledge economy. Oxford, UK: Oxford University Press.

Arvidsson, A., Caliandro, A., Cossu, A., Deka, M., Gandini, A., Luise, V., Oria, B. ... Anselmi, G. (2016). Commons based peer production in the information economy. Retrieved from https:// blog.p2pfoundation.net/commons-based-peer-production-informationeconomy/2016/10/21 (accessed on 12 November 2016).

Arvidsson, A., \& Peitersen, N. (2013). The ethical economy: Rebuilding value after the crisis. New York, NY: Columbia University Press.

Bardhi, F., \& Eckhardt, G.M. (2012). Access-based consumption: The case of car sharing. Journal of Consumer Research, 39, 881-898.

Becker, H. W. (1974). Art as collective action. American Sociological Review, 39, 767-777. Beckert,

J., \& Aspers, P. (2011). The worth of goods: Valuation and pricing in the economy. New York, NY: Oxford University Press.

Benkler, Y. (2004). 'Sharing nicely': On shareable goods and the emergence of sharing as a modal-ity of economic production. The Yale Law Journal, 114, 273-358.

Benkler, Y. (2006). The wealth of networks: How social production transforms markets and freedom. New Haven, CT: Yale University Press.

Benkler, Y. (2010). The idea of access to knowledge movement and information commons: Long-term trends and basic elements. In A. Kapczynski \& G. Krikorian (Eds.), Access to knowledge in the age of intellectual property (pp. 217-236). New York, NY: Zone Books.

Berger, P. L., \& Luckmann, T. (1967). The social construction of reality: A treatise in the sociology of knowledge. London, UK: Penguin Books.

Blumer, H. (1969). Symbolic interactionism: Perspective and model. Upper Saddle River, NJ: Prentice-Hall.

Botsman, R., \& Rogers, R. (2010). What's mine is yours: The rise of collaborative consumption. New York, NY: Harper Collins Publishers.

Braudel, F. (1977). Afterthoughts on material civilization and capitalism. Baltimore, MD: Johns Hopkins University Press.

Callon, M., Millo Y., \& Muniesa F. (Eds.). (2007). Market devices. Malden, MA: Blackwell.

Castells, M. (2000). The rise of the network society. Malden, MA: Blackwell.

Coleman, G. (2013). Coding freedom: The ethics and aesthetics of hacking. Princeton, NJ: Princeton University Press. 
Connell, R. (2007). Southern theory: The global dynamics of knowledge in social science. Sydney, NSW: Allen and Unwin.

Dupuy, F. (2004). Sharing knowledge: The why and how of organizational change. New York, NY: Palgrave Macmillan.

Dyer-Witheford, N. (2015). Cyber-proletariat: Global labour in the digital vortex. Chicago, IL: University of Chicago Press.

Esposito, R. (2010). Communitas: The origins and destiny of community. Stanford, CA: Stanford University Press.

Esposito, R. (2016). Persons and things: From the body's point of view. Malden, MA: Polity Press.

Fuchs, C. (2014). Digital labour and Karl Marx. New York, NY: Routledge.

Gandini, A. (2016). The reputation economy: Understanding knowledge work in digital society. London: Palgrave Macmillan.

Geertz, C. (1963). Peddlers and princes: Social development and economic changes in two Indonesian towns. Chicago, IL: University of Chicago Press.

Geertz, C. (1978). The bazaar economy: Information and search in peasant marketing. American Economic Review, 68, 28-32.

Granovetter, M. (1985). Economic action and social structure: The problem of embeddedness. American Journal of Sociology, 91, 481-510.

Howard, M. C. (1985). Fernand Braudel on capitalism: A theoretical analysis. Historical Reflections/Reflexions Historiques, 12, 469-483.

Kelty, C. (2008). Two bits: The cultural significance of free software. Durham, NC: Duke University Press.

Kostakis, V., \& Bauwens, M. (2014). Network society and future scenarios for a collaborative economy. London, UK: Palgrave Macmillan.

Liang, L. (2010). Beyond representation: The figure of the pirate. In A. Kapczynski \& G. Krikorian (Ed.), Access to knowledge in the age of intellectual property (pp. 277-292). New York, NY: Zone Books.

Liang, L., \& Sundaram, R. (2011). India. In J. Karaganis (Ed.), Media piracy in emerging economies (pp. 339-398). New York, NY: Social Science Research Council.

Lobato, R. (2014). The paradoxes of piracy. In L. Eckstein \& A. Schwarz (Eds.), Postcolonial piracy: Media distribution and cultural production in the global south (pp. 121-134). London, UK: Bloomsbury Academic.

Mason, P. (2015). Postcapitalism: A guide to our future. London, UK: Allen Lane.

Mathews, G. (2007). Chungking mansions: A centre of lower-end globalization. Ethnology, 46, 169-183.

Nakassis, C.V. (2013). Brands and their surfeits. Cultural Anthropology, 28, 111-126.

O'Mahony, S. (2006). Developing community software in a commodity world. In M. S. Fisher \& G. Downey (Eds.), Frontiers of CAPITAL: Ethnographic reflections on the new economy (pp. 237-266). Durham, NC: Duke University Press.

Pais, I., \& Provasi, G. (2015). Sharing economy: A step towards the re-embeddedness of the econ-omy? Stato e Mercato, 3, 347-378.

Parikka, J. (2012). What is media archaeology? Cambridge, UK: Polity.

Polanyi, K. (1975). The great transformation: The political and economic origins of our times. New York, NY: Octagon Books.

Polanyi, M. (1958). Personal knowledge: Towards a post-critical philosophy. London, UK: Routledge.

Polanyi, M. (1983). The tacit dimension. Gloucester, MA: Peter Smith.

Ray, T. (2009). Rethinking Polanyi's concept of tacit knowledge: From personal knowing to imag-ined institutions. Minerva, 47, 75-92. 
Raymond, E. S. (1999). The cathedral and the bazaar: Musings on Linux and open source by an accidental revolutionary. Sebastopol, CA: O'Reilly.

Roy, T. (2009). The guild in modern south Asia. In J. Lucassen, T. D. Moor \& J. L. Van Zanden (Eds.), The return of the guilds (pp. 95-120). Cambridge, UK: Cambridge University Press. Serafini, L. (2017). Beyond the person: Roberto Esposito and the body as 'common good'. Theory, Culture and Society, 34, 215-228.

Scholz, T. (2016). Platform cooperativism: Challenging the corporate sharing economy. New York, NY: Rosa Luxemburg Stiftung.

Sundaram, R. (2010). Pirate modernity: Delhi's media urbanism. New York, NY: Routledge.

Thompson, E. A. (2011). Trust is the coin of the realm: Lessons from the money men in Afghanistan. Oxford, NY: Oxford University Press.

Vähämäki, J. (2005). The mimetic turn of economy. Ephemera, 5, 791-794.

Zaleski, A. (2016). The rise and fall of the everyman tycoon. Retrieved from https://backchannel. com/the-3d-printing-revolution-that-wasnt-60b000c3a3ed\# (accessed on 5 April 2017).

\section{Author biography}

Maitrayee Deka is postdoctoral research fellow at the University of Milan on the EU-FP7 project P2Pvalue and now lecturer in Media and Social Theory in the Department of Sociology at the University of Essex. She achieved her MPhil in Sociology at Delhi School of Economics and has a PhD in Sociology. Her research interests focus on pirate economy, new media and economic sociology.

iUpdated citation please find here: http://journals.sagepub.com/toc/SOR/current 